Огляди літератури, оригінальні дослідження, погляд на проблему, випадок з практики, короткі повідомлення УДК 544.023.223-1+616-089.8+616-001.4+616.33+616-092.9

DOI 10.11603/1811-2471.2019.v0.i2.10385

\title{
РЕЗУЛЬТАТИ ПАТОМОРФОЛОГІЧНОГО ТА ФІЗИЧНОГО ДОСЛІДЖЕННЯ ВПЛИВУ БІОДЕГРАДУЮЧОЇ ПОЛІМЕРНОЇ ПЛІВКИ «БІОДЕП ДФ॥ НА МІЦНІСТЬ РУБЦЯ ПІСЛЯОПЕРАЦІЙНОЇ РАНИ ШЛУНКА В ЕКСПЕРИМЕНТІ
}

\author{
○о. Я. Попадюк, В. М. Костюк, М. М. Волошин \\ ДВНЗ «Івано-Франківський національний медичний університет»
}

РЕЗЮМЕ. Міцність швів у шлунково-кишковій хірургії є складною та невирішеною проблемою, що може бути причиною прогресування захворювання й навіть смерті. Для забезпечення герметичності швів застосовують різноманітні додаткові засоби: клеї, плівки, біополімерні композиції. На жаль, ці композиції недостатньо ефективні або маловивчені.

Мета - дати патоморфологічну та фізичну оцінку впливу біодеградуючої полімерної плівки «Біодеп-ДФ» на міцність рубця післяопераційної рани шлунка в експерименті.

Матеріал і методи. Дослідження проводили на 65 морських свинках з дотриманням усіх міжнародних вимог. На розробленому нами ранотензіометрі вивчали міцність рубців післяопераційних ран шлунка без додаткових засобів герметизації та з накладанням біодеградуючої полімерної плівки, насиченої декаметоксином та нанорозмірним гідратованим фулереном $\mathrm{C}_{60}$. Морфологічні дослідження проводили на базі кафедри патоморфології та судової медицини ДВНЗ «вано-Франківський національний медичний університет».

Результати. У групі без лікування на 1 добу відбувався розрив рубця під вагою $(25,0 \pm 1,6)$ г, що на 7,2 г менше ніж у групі III. На 7 добу вага на розрив у групі III перевищувала вагу контрольної групи на 46,8 г. Уже на 10 добу спостерігали розрив тканин вище та нижче рубця за однакової ваги, наближеної до ваги після накладання швів.

У II групі на 3 добу в стінці шлунка переважали процеси некрозу, натомість у III групі спостерігали розростання грануляційної тканини на фоні запальної клітинної інфільтрації. Вже на 7 добу експерименту в тварин III групи утворювалась сполучна тканина, що свідчить про регенерацію пошкоджених тканин, а в II групі на 7 добу зберігалася запальна інфільтрація слизової оболонки шлунка.

Висновки. Розроблена полімерна плівка $\epsilon$ еластичною, дозовано виділяє діючу речовину та збільшує міцність рубця рани шлунка у післяопераційному періоді.

КлючовІ СловА: полімерна плівка; рана; шлунок; експеримент.

Вступ. Незважаючи на розвиток хірургії та появу новітніх методів діагностики, лікування, нових методів накладання швів, не завжди забезпечується цілісність анастомозів у шлунково-кишковій хірургії, що може бути причиною прогресування захворювання та залишається на сьогодні невирішеною проблемою [1].

Кінцевий анастомоз, що добре функціонує, незважаючи на правильність його накладання, може спричинити вихід шлунково-кишкового вмісту та можливе виникнення перитоніту. В найближчому післяопераційному періоді шви вразливі до підвищеного внутрішньокишкового тиску, тому існують вимоги для забезпечення міцності анастомозу [2, 3].

Ідеальний пристрій чи спосіб для накладання анастомозів повинен забезпечити добру міцність з'єднання, що не вимагає перешивання анастомозу чи застосування стороннього матеріалу [4].

Крім використання різних видів швів, з метою забезпечення їх герметичності вивчають у експерименті та застосовують у клініці різноманітні додаткові засоби - клеї, плівки, біополімерні композиції $[5,6]$. На жаль, ці композиції не мають достатньої ефективності або мало вивчені.

Ми розробили сучасний полімерний матеріал у вигляді біодеградуючої полімерної плівки
«Біодеп-ДФ» (Рішення про видачу деклараційного патенту на корисну модель №12462/3У/18 від 16.05.18 р. Заявка № ч201801783), який може додатково застосовуватись для підвищення герметичності швів та покращення загоєння ран у післяопераційному періоді.

Мета - дати патоморфологічну та фізичну оцінку впливу біодеградуючої полімерної плівки «Біодеп-ДФ» на міцність рубця післяопераційної рани шлунка в експерименті.

Матеріал і методи дослідження. У дослідженні брали участь 65 тварин. Дослідження проводили в операційній клініко-біологічної бази «Віварій» ДВНЗ «Івано-Франківський національний медичний університет».

Попередні дослідження на 10 тваринах показали певні недоліки вивчення міцності такого рубця шлунка зі швами на ранотензіометрі. При поступовому збільшенні навантаження на ділянки шлунка з рубцем відбувався розрив інтактної ділянки шлунка вище або нижче рубця та у ділянці проколів голкою стінки шлунка (вага $(196 \pm 3,1)$ г на 1 добу та $(210,2 \pm 1,8)$ г на 3 добу). Стінка шлунка сильно розтягувалась, а сам рубець залишався цілий. На нашу думку, це було пов'язано з тим, що накладені шви щільно фіксували та утримували 
Огляди літератури, оригінальні дослідження, погляд на проблему, випадок з практики, короткі повідомлення краї рани і не давали рубцю можливості розійтись. Це не давало об'єктивної оцінки вивчення міцності рубця та не давало справжньої характеристики міцності зрощення тканин у періоди дослідження. Тому ми вирішили провести вказане дослідження після зняття швів, що дозволило більш інформативно та об'єктивно оцінити міцність післяопераційного шва шлунка.

Основний етап дослідження проводився на 55 морських свинках (виду Мурчаки) вагою $(293,9 \pm 22,6)$ г. Тварин утримували та годували згідно з санітарно-гігієнічними вимогами, нормами та правилами Європейської конвенції про захист хребетних тварин (European convention for the protection of vertebrate animals used for experimental and other scientific purposes. - Counsil of Europe. - Strasburg, 1986) [7].

Напередодні оперативного втручання на шлунку тварин протягом 2 діб не годували та утримували в окремих клітках за однакових умов. Для вивчення міцності тканин та післяопераційного рубця шлунка тварин поділили на групи: група I 5 тварин, в яких проводили вивчення міцності неоперованих тканин шлунка; група II - 20 тварин, яким не проводили додаткового лікування; група III - 20 особин, яким на ділянку рубця накладали біодеградуючу полімерну плівку «Біодеп-ДФ» довжиною 20 мм, шириною - 10 мм та товщиною 0,5 мм, насичену відомим засобом протимікробної дії декасаном (концентрація декаметоксину 0,2 мг/мл) та сучасним засобом протекторної та дезінтоксикаційної дії нанорозмірним гідратованим фулереном $\mathrm{C}_{60} 3$ розрахунку 1 мкг/мл; група IV - 5 тварин, інтактні тварини, за якими спостерігали без хірургічного лікування.

Під загальним знеболюванням оксибутиратом нартію з розрахунку 0,15 мг на 100 г ваги тварини з дотриманням усіх правил асептики та стерильності в операційній віварію обробляли передню черевну стінку 5 \% розчином йоду, проводили серединну лапаротомію, лінійно розсікали стінку шлунка довжиною 15 мм. Атравматичною голкою 3 ниткою полігліколід 6.0 ушивали рану шлунка однорядним швом та тваринам основної групи накладали смужку підготовленої полімерної плівки на шов. Передню черевну стінку ушивали пошарово з накладанням асептичної пов'язки. У післяопераційному періоді тварин поїли теплою водою та давали рідку їжу. Звичайну їжу давали тваринам 35 доби. Тваринам щоденно проводили перев'язку з обробкою ран передньої черевної стінки йодним розчином та оцінювали їхню поведінку. Термін спостереження становив 1, 3, 7, та 10 доба відповідно, тварин виводили з експерименту шляхом евтаназії згідно з вимогами [European Union. Directive 2010/63/EU of the European Parliament and of the Council of 22 September 2010 on the Protection of Animals Used for Scientific Purposes.] (введення внутрішньовенно $1 \%$ розчину тіопенталу натрію у дозі, втричі більшій за терапевтичну) та виконували релапаротомію. Оцінювали рубець шлунка, стан навколишніх тканин, наявність чи відсутність запальних реакцій.

Міцність післяопераційного рубця вивчали на розробленому нами механічному ранотензіометрі - MP1 (патент України на корисну модель UA 123115 від 12.02.2018 р., Бюл. № 3). Після зняття швів смужку стінки шлунка довжиною 20 мм та шириною 10 мм лінійно розтягували та фіксували, при якій вазі відбувався розрив тканин.

Морфологічні дослідження проводили на базі кафедри патоморфології та судової медицини ДВНЗ «Івано-Франківський національний медичний університет». Матеріал, отриманий після виведення тварин з експерименту, фіксували 48 годин у $10 \%$ розчині нейтрального забуференого формаліну, а далі зневоднювали у висхідній батареї спиртів та здійснювали парафінову заливку. На санному мікротомі робили серійні гістологічні зрізи завтовшки 5 мкм. Після депарафінізації зрізів препарати забарвлювали гематоксиліном та еозином і аналізували їх на мікроскопі Carl ZEISS Axiostar plus (Microlmaning, Німеччина), о6ладнаному фотокамерою Canon G 10 для отримання цифрових зображень.

Усі дослідження проводили з визначенням середніх значень і статистичною обробкою даних з внесенням результатів у відповідні таблиці. Застосовували параметричну описову статистику, використовували ліцензійні пакети статистичного аналізу Microsoft Excel.

Результати й обговорення. Розрив стінки шлунка, що не був оперований, відбувався під вагою $(230,2 \pm 3,0)$ г.

Після зняття швів розрив рубця на 1 добу в II групі відбувався під вагою $(25,0 \pm 1,6)$ г, що на 7,2 г менше, ніж у III групі $(32,2 \pm 2,5)$ г. На 3 добу результати дещо відрізнялись, а саме, показник ваги у III групі тварин перевищував показники групи II на 24 г і становив $(67,0 \pm 2,7)$ г. Уже на 7 добу розрив у III групі відбувся під вагою близько $(205,0 \pm 3,8)$ г, а у групі II - під вагою $(158,2 \pm 3,0)$ г, що на 46,8 г менше, ніж у групі III. Уже на 10 добу спостерігали розрив тканин вище та нижче рубця за однакової ваги, наближеної до ваги після накладання швів.

Проведені морфологічні дослідження показали, що на першу добу після виведення тварин 3 експерименту в II та III групах слизова оболонка шлунка в місці проведення хірургічного втручання була тотально некротизована (а) з масивними ділянками інфільтрації поліморфноядерними лейкоцитами та макрофагами (6) (рис. 1). 
Огляди літератури, оригінальні дослідження, погляд на проблему, випадок з практики, короткі повідомлення

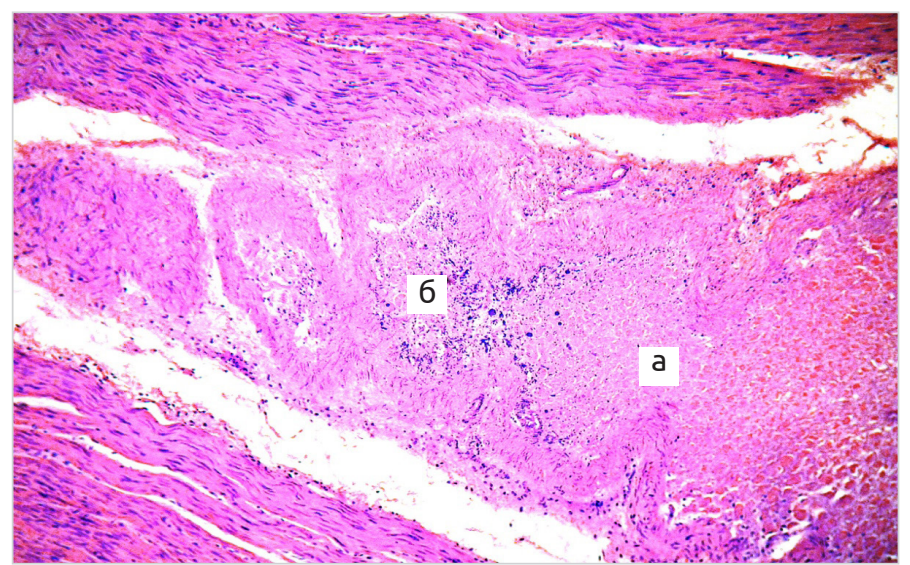

Рис. 1. II група тварин. Слизова оболонка шлунка з тотальним некрозом (а) та поліморфноклітинною запальною інфільтрацією (б). Забарвлення гематоксиліном і еозином. Збільшення: окуляр 10, об'єктив 10.

На 3 добу в II групі спостерігали тотальний некроз слизової оболонки шлунка (а) з вогнищевою запальною інфільтрацією нейтрофільними лейкоцитами ії базальної пластинки (б) та набряком субмукозного простору (в) (рис. 2). у III групі досліджуваних тварин відмічали вогни- щеву лімфолейкоцитарну запальну інфільтрацію слизової оболонки (а) з частковою фрагментацією гладком'язових волокон (6) стінки шлунка на фоні вираженого повнокров'я судин переважно в ділянці базальної пластинки (в) (рис. 3).

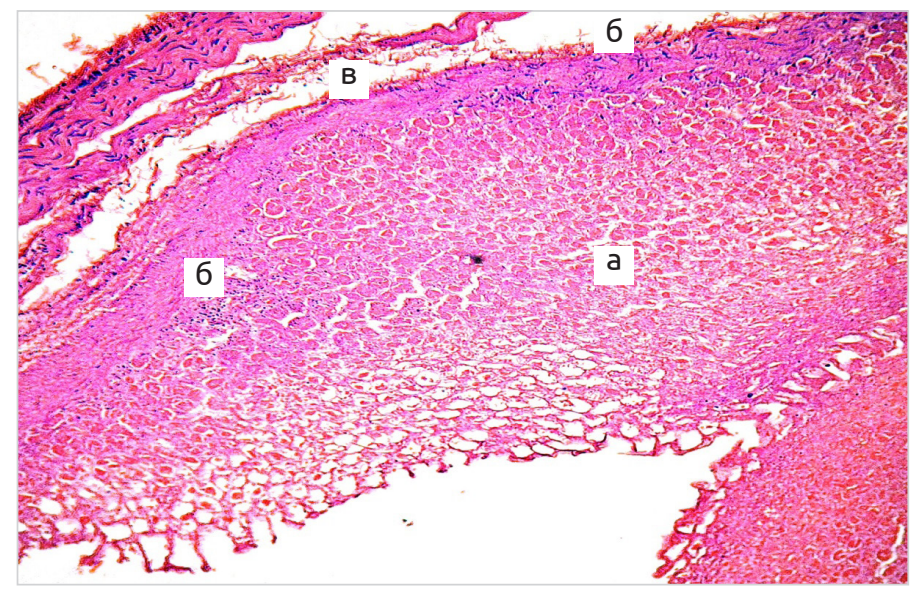

Рис. 2. II група тварин. Слизова оболонка шлунка з тотальним некрозом (а) та вогнищевою інфільтрацією власної пластинки (6). Набряк підслизового простору (в). Забарвлення гематоксиліном і еозином. 36ільшення: окуляр 10, об'єктив 10.

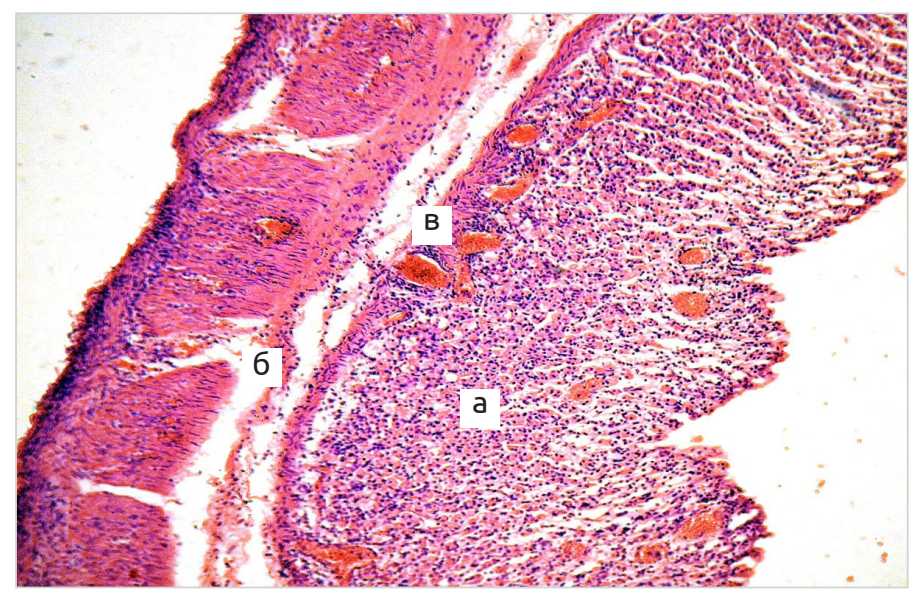

Рис. 3. III група тварин. Слизова оболонка шлунка із запальною інфільтрацією (а). Фрагментація гладком'язових волокон (6). Повнокров'я судин (в). Забарвлення гематоксиліном і еозином. Збільшення: окуляр 10, об'єктив 10. 
Огляди літератури, оригінальні дослідження, погляд на проблему, випадок з практики, короткі повідомлення

На 7 добу експерименту в II групі тварин відмічали помірний набряк строми слизової оболонки шлунка з вогнищами лімфоцитарної запальної інфільтрації (а) та розростання сполучної тканини серед м'язових волокон (6) (рис. 4).
На 7 добу експерименту в III групі та на 10 добу в II та III групах тварин на фоні відсутності клітинної імунної відповіді організму спостерігали вогнищеву фрагментацію гладком'язових волокон (а), розростання сполучної тканини (б) в стінці шлунка та набряк субмукозного простору (в) (рис. 5).

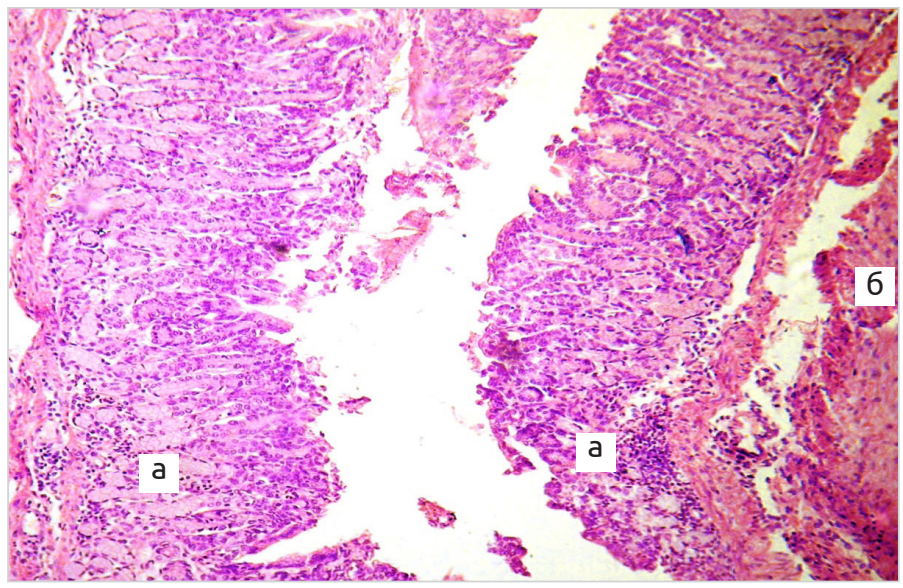

Рис. 4. II група тварин. Вогнища лімфоцитарної інфільтрації (а). Розростання сполучнотканинних волокон (6). Забарвлення гематоксиліном і еозином. Збільшення: окуляр 10, об'єктив 10.

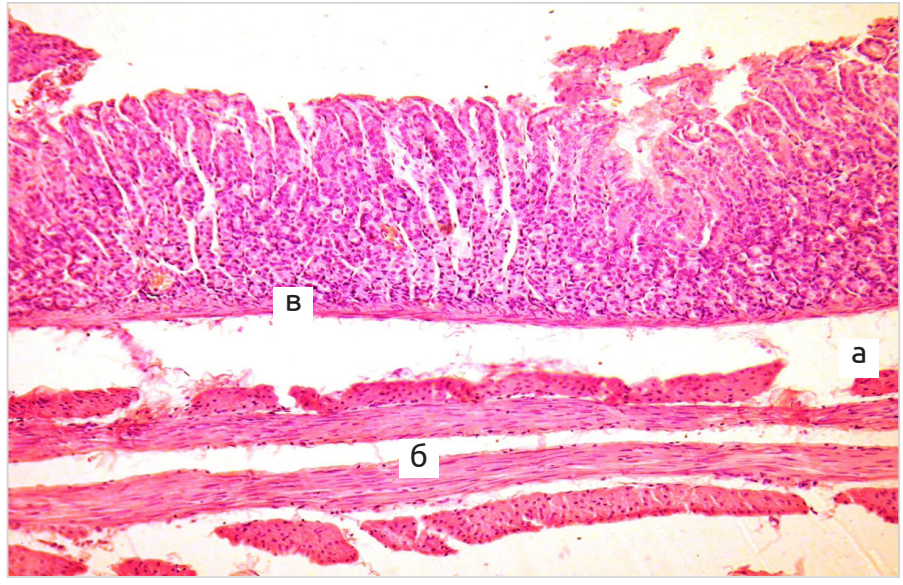

Рис. 5. III група тварин. Фрагментація гладком'язових волокон (а). Волокниста сполучна тканина (6). Набряк субмукозного простору (в). Забарвлення гематоксиліном і еозином. Збільшення: окуляр 10, об'єктив 10.

Результати проведеного нами дослідження показали, що на 1 та 10 доби експерименту морфологічна характеристика стінки шлунка в II досліджуваній групі суттєво не відрізняється від тварин III групи. На першу добу експерименту переважають некротичні та запальні реакції в стінці шлунка, як наслідок пошкодження в результаті оперативного втручання. На 10 добу експерименту ми спостерігали розростання зрілої сполучної тканини та часткову фрагментацію гладком'язових волокон, як наслідок розриву стінки шлунка.

Разом з тим, ми виявили істотну різницю між загоєнням післяопераційної рани шлунка тварин досліджуваних груп тварин в терміні 3 та 7 діб. У тварин II групи на 3 добу в стінці шлунка переважали процеси некрозу, що свідчить про прогресування реакцій альтерації. Натомість у III групі спостерігали розростання грануляційної тканини на фоні запальної клітинної інфільтрації, що свідчить про активацію репаративних процесів у зоні пошкодження. Вже на 7 добу експерименту в III групі тварин відмічено утворення сполучної тканини, що свідчить про регенерацію пошкоджених тканин як наслідок оперативного втручання та фрагментацію гладком'язових волокон - як наслідок механічного розриву стінки шлунка. А в II групі тварин на 7 добу продовжували спостерігати реакції клітинного імунітету у вигляді запальної інфільтрації слизової оболонки шлунка. 
Огляди літератури, оригінальні дослідження, погляд на проблему, випадок з практики, короткі повідомлення

Дані літературних джерел вказують, що процес загоєння ран шлунково-кишкового тракту відбувається за тими ж законами, що й ран м'яких тканин, - з явищами запалення, фібринолізу і дозріванням сполучної тканини рубця [9].

Формування різних видів анастомозів механічної регенерації в зоні рубця, отриманих різними способами (накладанням ручних наскрізних чи багаторядних швів, швів, сформованих лазером чи апаратним з'єднанням), визначає міцність післяопераційної рани шлунка чи кишечника. Вивчення механічної міцності $€$ важливим критерієм оцінки загоєння таких швів і повинно бути максимально об'єктивним. Саме тому в дослідженні ми застосовували удосконалений ранотензіометр, який забезпечує легкість застосування та високу точність вимірювання завдяки своїм конструктивним особливостям, можливості врівноважувати верхній та нижній затискачі, розподіляючи силу натягу на досліджуваний елемент тканини рубця рівномірно. Запропонований спосіб дослідження рубця після зняття швів дозволяє визначити міцність зрощення тільки тканин, без урахування утримувальної дії швів. Отримані механічні результати показали, що застосування розробленої нами біодеградуючої полімерної плівки підвищує міцність післяопераційного рубця починаючи 31 доби, а патоморфологічні результати показали ефективний вплив на регенерацію тканин починаючи з 3 доби. Крім того, вже на 7 добу міцність рубця наближається до показника інтактних тканин. Все ж слід зазначити, що в період з 7 до 10 доби відбувається розрив не самого рубця, а розрив тканин вище й нижче рубця, навіть після зняття швів. Дані у джерелах літератури стосовно вивчення механічних параметрів післяопераційного рубця після накладання різних видів швів вказують, що механічна міцність післяопераційного рубця до 4 доби знижується, у зв'язку з відсутністю колагену як будівельного матеріалу для регенерації, а з 5 до 10 доби наростає, та на 10 добу стає подібною до міцності інтактної тканини [8]. Це свідчить про високу міцність рубця та слабкість тканин, наближених до рубця, які, можливо, ослаблені в ділянці проколів. Така ефективність розробленої нами полімерної плівки обумовлена механізмом ії дії, що забезпечується особливим складом та властивостями. Плівка $\epsilon$ еластичною, що забезпечує зручність у її застосуванні, добре прилягає та фіксується з прилеглими тканинами в ранні терміни використання, тим самим зберігаючи герметичність шва та щільний контакт з тканинами. Біодеградуючі властивості, а саме - поступова втрата зв'язків між компонентами під дією рідини, забезпечують поступове ви- вільнення активних речовин у місці аплікації та їх дію у ділянці ураження. У своєму складі плівка має гліцерин, як пластифікатор та допоміжна речовина, що допомагає гідрофілізувати поверхність гідрофобних частин [10], Застосування нами желатину є виправданим та, в поєднанні з полівініловим спиртом, показало його ефективність у можливості корекції деградації плівки в часі, позитивний вплив на репаративні процеси. Підтвердженням цього $є$ результати застосування плівок з вмістом желатину, отримані іншими науковцями. Желатин ефективно впливає на репаративні процеси в ділянці застосування, як полімер без видової специфічності забезпечує повне виділення діючих речовин в організм, має добрі технологічні параметри і добре фіксується за рахунок власної адгезії, що забезпечує чітку дію в ділянці контакту [11].

Застосування декаметоксину забезпечило високий протимікробний захист, а нанорозмірний гідратований фулерен $\mathrm{C}_{60}$ забезпечив місцевий антиоксидантний ефект та активацію фібропластичної реакції.

Висновки. 1. Біодеградуюча полімерна плівка «Біодеп ДФ» має добрі біодеградуючі властивості, дозовано виділяє діючу речовину, сприяє кращому загоєнню післяопераційної рани та поліпшує герметизацію шва шлунка у ранньому післяопераційному періоді.

2. Вивчення міцності рубця шлунка на розробленому нами ранотензіометрі після зняття швів точніше показує стан загоєння післяопераційної рани у ранньому післяопераційному періоді.

3. Патоморфологічно доведено, що біодеградуюча полімерна плівка покращує регенерацію тканин у межах третьої та сьомої діб, порівняно з загоєнням ран без застосування додаткових засобів герметизації.

4. Біодеградуючі полімерні плівки «Біодеп-ДФ» $\epsilon$ сучасним додатковим засобом герметизації швів після операцій на органах шлунково-кишкового тракту та потребують подальшого експериментального й клінічного дослідження з наступним впровадженням у клініку.

Перспективи подальших досліджень. Подальше всестороннє експериментальне вивчення розробленої нами біодеградуючої полімерної плівки дозволить виявити усі недоліки та переваги ії застосування, що, в свою чергу, дасть можливість провести клінічні випробування та впровадження у клінічну практику, зменшити кількість ускладнень, пов'язаних з недостатністю швів у хірургії шлунково-кишкового тракту, підвищити міцність та герметичність швів післяопераційних ран.

Конфлікт інтересів відсутній. 
Огляди літератури, оригінальні дослідження, погляд на проблему, випадок з практики, короткі повідомлення ЛІТЕРАТУРА

1. Каримов Е. Я. Структура й аналіз неспроможності швів за результатами роботи хірургічного відділення / Е. Я. Каримов, Е. Б. Усеїнов, Н. Н. Торотадзе // Шпитальна хірургія. - 2009. - № 1. - С. 52-55.

2. Sutureless functional end-to-end anastomosis using a linear stapler with polyglycolic acid felt for intestinal anastomoses / M. Naito, H. Miura, T. Nakamura [et al.] // Ann. Med. Surg. (Lond). - 2017. - No. 31 (17). - P. 50-53. DOI: 10.1016/j.amsu.2017.03.037. eCollection 2017 May.

3. Каминский И. В. Клинико-экспериментальное обоснование применения прецизионного кишечного шва у больных с высокой степенью вероятности возникновения послеоперационных осложнений / И. В. Каминский, Е. Б. Чемоданов // Український журнал хірургії. 2014. - № 1 (24). - С. 86-93.

4. Compression anastomosis clips versus a hand-sewn technique for intestinal anastomosis in pigs / K. Kuśnierz, M. Kajor, D. Zaworonkow [et al.] // Adv. Clin. Exp. Med. 2015. - No. 24 (6). - P. 1019-1029. DOI: 10.17219/ acem/50070.

5. Шуленбаев А. С. Герметизация желудочно-кишечных анастомозов препаратом Тахокомб в условиях «компрометированной» кишечной стенки / А. С. Шуленбаев // Вестник хирургии Казахстана. - 2011. - № 3. C. 24-25.

\section{REFERENCES}

1. Karymov, E.Ya., Useinov, E.B., \& Torotadze, N.N. (2009). Struktura i analiz nespromozhnosti shviv za rezultatamy roboty khirurhichnoho viddilennia [Structure and analysis of insolvency of seams by results of operation of surgical department]. Shpytalna khirurhiia - Hospital Surgery, 1, 52-55 [in Ukrainian].

2. Naito, M., Miura, H., Nakamura, T., Sato, T.1, Yamanashi, T., Tsutsui, A., \& Watanabe, M. (2017). Sutureless functional end-to-end anastomosis using a linear stapler with polyglycolic acid felt for intestinal anastomoses. Ann. Med. Surg. (Lond), 17, 50-53. doi: 10.1016/j. amsu.2017.03.037. eCollection 2017 May.

3. Kaminskiy, I.V., \& Chemodanov, E.B. (2014). Klinikoeksperimentalnoye obosnovaniye primineniya pretsizionnogo kishechnogo shva u bolnykh s vysokoy stepenyu veroyatnosti vozniknoveniya posleoperatsionnykh oslozhneniy [Clinical and experimental substantiation of the application of precision intestinal suture in patients with a high probability of occurrence of postoperative complications]. Ukrainskyi zhurnal khirurhii - Ukrainian Journal of Surgery, 1 (24), 86-93 [in Russian].

4. Kuśnierz, K., Kajor, M., Zaworonkow, D., Lekston, Z., Ciupińska-Kajor, M., Seweryn, M., \& Lampe, P. (2015). Compression anastomosis clips versus a hand-sewn technique for intestinal anastomosis in pigs. Adv. Clin. Exp. Med., 24 (6), 1019-1029. doi: 10.17219/acem/50070.

5. Shulenbaev, A.S. (2011). Germetizatsiya zheludochno-kishechnykh anastomozov preparatom taxokomb v usloviyakh "komprometirovannoy" kishechnoy stenki [Sealing of gastrointestinal anastomoses with Tachocomb in conditions of "compromised" intestinal wall]. Vestnik khi-
6. Черноусов А. Ф. Опыт применения фибринового клея для лечения несформированных свищей желудочно-кишечного тракта / А. Ф. Черноусов, Т. В. Хоробрых, О. В. Ищенко // Хирургия. Журнал им. Н. И. Пирогова. - 2006. - № 9. - С. 21-24.

7. Попадюк О. Я. Патоморфологічні особливості відновлення пошкоджених м'яких тканин із застосуванням біорозчинної полімерної плівки в експерименті / О. Я. Попадюк // Український журнал хірургії. - 2013. № 4 (23). - С. 67-72.

8. Взгляд на механическую прочность кишечного анастомоза / Ф. Ш. Алиев, И. А. Чернов, О. А. Молокова [и др.] // Бюллетень сибирской медицины. - 2003. № 2. - С. 89-93.

9. Егоров В. И. Механические методы оценки заживления желудочно-кишечных соединений / В. И. Егоров // Анналы хирургии. - 2001. - № 3. - С. 25-28.

10. Настанова СТ-Н МОзУ 42-4.0:2015. Лікарські засоби. Належна виробнича практика (затверджена наказом Міністерства охорони здоров'я України від 30.07.2015. - № 478.

11. Применение лекарственных препаратов на основе желатина / В. Н. Ананьев, В. А. Фурин, Л. П. Ларионов, Ю. Т. Новиков [и др.] // Вестник РУДН, серия Медицина. - 2009. - № 4. - С. 621-622.

rurhii Kazakhstana - Bulletin of Kazakhstan Surgery, 3, 2427 [in Russian].

6. Chernousov, A.F., Chorobrykh, T.V., \& Ishchenko, O.V. (2006). Opyt primeneniya fibrinovogo kleya dlya lecheniya nesformirovannykh svishchey zheludochno-kishechnogo trakta [Experience in the use of fibrin glue for the treatment of unformed fistula of the gastrointestinal tract]. Khirurgiya. Zhurnal im. N. I. Pirogova - Surgery. Journal named after N.I. Pirogov, 9, 21-24 [in Russian].

7. Popadiuk, O.Ya. (2013). Patomorfolohichni osoblyvosti vidnovlennia poshkodzhenykh miakykh tkanyn iz zastosuvanniam biorozchynnoi polimernoi plivky v eksperymenti [Pathomorphological features of restoration of damaged soft tissue using biodegradable polymer film in the experiment.]. Ukrainskyi zhurnal khirurhii - Ukrainian Journal of Surgery, 4 (23), 67-72 [in Ukrainian].

8. Aliyev, F.Sh., Chernov, I.A., Molokova, O.A., Kecherukov, A.I., Gyunter, V.E., \& Baradulin, A.A. (2003). Vzglyad na mekhanicheskuyu prochnost kishechnogo anastomoza [A look at the mechanical strength of the intestinal anastomosis]. Byulleten Sibirskoy meditsiny - Bulletin of Siberian Medicine, 2, 89-93 [in Russian].

9. Egorov, V.I. (2001). Mekhanicheskiye metody otsenki zazhivleniya zheludochno-kishechnykh soyedineniy [Mechanical methods for assessing the healing of gastrointestinal]. Annaly khirurgii -Annals of Surgery, 3, 25-28 [in Russian].

10. Nastanova, ST-N MOZU 42-4.0:2015. Likarski zasoby. Nalezhna vyrobnycha praktyka (zatverdzhena nakazom Ministerstva okhorony zdorovia Ukrainy vid 30.07.2015 № 478 [Instruction ST-N MOHU 42-4.0: 2015. Medicines. 
Огляди літератури, оригінальні дослідження, погляд на проблему, випадок з практики, короткі повідомлення Good Manufacturing Practice (approved by the order of the Ministry of Health of Ukraine of 30.07.2015, No. 478] [in Ukrainian].

11. Ananev, V.N. Furin, V.A., Larionov, L.P., Novikov, Yu.T., Fatihov, I.M., Latenkova, N.Yu., Gatsko, Yu.S., \&

Ananeva, O.V. (2009). Primeneniye lekarstvennykh preparatov na osnove zhelatina [The use of drugs based on gelatin]. Vestnik RUDN, seriia Meditsina - Bulltin of Russian University of People's Friendship, 4, 621-622 [in Russian].

\title{
РЕЗУЛЬТАТЫ ПАТОМОРФОЛОГИЧЕСКОГО И ФИЗИЧЕСКОГО ИССЛЕДОВАНИЯ ВЛИЯНИЯ БИОДЕГРАДИРУЮЩЕЙ ПОЛИМЕРНОЙ ПЛЕНКИ БИОДЕП ДФ" НА ПРОЧНОСТЬ РУБЦА ПОСЛЕОПЕРАЦИОННОЙ РАНЫ ЖЕЛУДКА В ЭКСПЕРИМЕНТЕ
}

\author{
๑О. Я. Попадюк, В. Н. Костюк, М. М. Волошин \\ ГВУз «Ивано-Франковский национальный медицинский университет»
}

РЕЗЮМЕ. Прочность швов В желудочно-кишечной хирургии является сложной и нерешенной проблемой, которая может быть причиной прогрессирования заболевания и даже смерти. Для обеспечения герметичности швов применяют различные дополнительные средства: клеи, пленки, биополимерные композиции. К сожалению, данные композиции недостаточно эффективны или малоизучены.

Цель - дать патоморфологическую и физическую оценку влияния биоразлагаемой полимерной пленки «Биодеп-ДФ» на прочность рубца послеоперационной раны желудка в эксперименте.

Материал и методы. Исследование проводили на 65 морских свинках с соблюдением всех международных требований. На разработанном нами ранотензиометре изучали прочность рубцов послеоперационных ран желудка без дополнительных средств герметизации и с наложением биоразлагаемой полимерной пленки, насыщенной декаметоксином и наноразмерным гидратированным фуллереном $\mathrm{C}_{60}$. Морфологические исследования проводили на базе кафедры патоморфологии и судебной медицины гвУз «Ивано-Франковский национальный медицинский университет».

Результаты. В группе без лечения на 1 сутки происходил разрыв рубца под весом $(25,0 \pm 1,6)$ г, что на 7,2 г меньше чем в группе III. На 7 сутки вес на разрыв в исследуемой группе превышал вес контрольной группы на 46,8 г. Уже на 10 сутки наблюдали разрыв тканей выше и ниже рубца при одинаковом весе, приближенном к весу после наложения швов.

Bo II группе на 3 сутки преобладали процессы некроза в стенке желудка, зато в III группе наблюдали разрастания грануляционной ткани на фоне воспалительной клеточной инфильтрации. Уже на 7 сутки эксперимента в исследуемой III группе образовывалась соединительная ткань, что свидетельствует о регенерации поврежденных тканей, а во II группе на 7 сутки оставалась воспалительная инфильтрация слизистой оболочки желудка.

Выводы. Разработанная полимерная пленка является эластичной, дозированно выделяет действующее вещество и повышает прочность рубца раны желудка в послеоперационном периоде.

кЛючЕВЫЕ СЛОВА: полимерная пленка; рана; желудок; эксперимент.

\section{RESULTS OF THE PATHOMORPHOLOGICAL AND PHYSICAL STUDY OF THE EFFECT OF A BIODEGRADABLE POLYMERIC FILM "BIODEP DF" ON THE STRENGTH OF THE POSTOPERATIVE WOUND OF THE STOMACH IN THE EXPERIMENT}

\author{
๑O. Ya. Popadyuk, V. M. Kostiuk, M. M. Voloshyn \\ Ivano-Frankivsk National Medical University
}

SUMMARY. The strength of seams in gastrointestinal surgery is a complex and unresolved problem that can be the cause of disease progression and even death. Various additional means are used to ensure seam sealing: adhesives, films, biopolymer compositions. Unfortunately, these tracks are not effective enough or were not poorly understood.

The aim of the study - to give a pathomorphological and physical assessment of the effect of biodegradable polymeric film "Biodept-DF" on the strength of the rumen of the postoperative wound of the stomach in the experiment.

Material and Methods. The study was carried out on 65 guinea-pigs in compliance with all international requirements. At the ron-tensiometer developed by us, we studied the strength of postoperative wounds of the stomach without the additional means of sealing and with the addition of a biodegradable polymeric film saturated with decamethoxin and nanosized hydrated fullerene C60. Morphological studies were conducted on the basis of the Department of Pathomorphology and Forensic Medicine of the Ivano-Frankivsk National Medical University. 
Огляди літератури, оригінальні дослідження, погляд на проблему, випадок з практики, короткі повідомлення

Results. In the group without treatment, for the first day there was a scar rupture under the weight of (25.0 \pm 1.6$) \mathrm{g}$, which is $7.2 \mathrm{~g}$ less than in the experimental group III. At the 7th day the weight of the gap in the experimental groups exceeded the weight of the control group by $46.8 \mathrm{~g}$. Already for the 10 th day, a rupture of tissue above and below the scar was observed for the same weight close to the weight after suturing.

In the group 2, on the 3rd day, the processes of necrosis in the stomach wall predominated, whereas in the group 3 , the growth of granulation tissue was observed on the background of inflammatory cellular infiltration. Already on the 7th day of the experiment, the connective tissue was formed in the study group 3, indicating the regeneration of damaged tissues, and in the group 2 on the 7th day, continued to observe inflammatory infiltration of the mucous membrane of the stomach.

Conclusions. The developed polymeric film is elastic, dosage separates the active substance and increases the durability of scar tissue wounds in the postoperative period.

KEY WORDS: polymer film; wound; stomach; experiment. 